\title{
PLASMA NT-PRO BNP AS AN EARLY MARKER OF CARDIO TOXICITY INDUCED BY ACUTE ORGANOPHOSPHATE POISONING
}

\author{
$\mathcal{B Y}$ \\ Samia A. Hasan, Maha El-Bakry, Sameera Sh. Hamed, Nermin M. Emam \\ and Ibrahim A. Abdel -Aal* \\ Forensic Medicine \& Clinical Toxicology and Clinical Pathology ${ }^{*}$ Departments, Faculty of Medicine, \\ Mansoura University, Egypt
}

\begin{abstract}
Organophosphorus $(O P)$ poisoning remains an important cause of morbidity and mortality in developing countries. Cardiac complications often accompany poisoning with these compounds, which are potentially preventable if they are recognized early and treated adequately. This study aimed to assess the potential benefit of plasma $N$-terminal pro brain natriuretic peptides (NT-proBNP) as an early marker of cardio toxicity induced by acute OP poisoning and to compare its beneficial value with the well-assessed cardiac markers serum "creatine kinase-MB (CK-MB) and cardiac Troponin I (cTnI)". This study was conducted on 150 individuals of both sexes. Participants were divided into three groups: Group I (control), group II (OP poisoning cases without cardiac signs) and group III (OP poisoning cases with cardiac signs). Serum levels of pseudocholinesterase (PCE), CK-MB, cTnI and plasma levels of NT-pro BNP were determined on admission. There were significant differences in plasma NT-proBNP levels between control group versus OP poisoned groups (II and III) and between groups II versus III with no significant differences regarding serum levels of $C K-M B$ and cTnI. It can be concluded that plasma NT-proBNP can be used as an early marker and a diagnostic screening tool for silent myocardial stress that may occur early during the acute course of OP poisoning.
\end{abstract}

Keywords: Organophosphates, cardio toxicity, cardiac markers, NT-proBNP, Troponin I, creatinekinase-MB.

\section{INTRODUCTION}

Organophosphorus compounds (OPC) are used extensively around the world as pesticides, herbicides and chemical warfare agents. Acute poisoning by
OPC is a major global clinical problem (Kumar et al., 2010). Poisoning with OPC frequently causes ill health and death particularly in developing countries (Aardema et al., 2008). 
Myocardial injury is a strong predictor of death in patients with OP poisoning (Aghabiklooei et al., 2013). The cardiac toxicity associated with OP poisoning is caused by sympathetic and parasympathetic over-activity, hypoxemia, metabolic acidosis, electrolyte derangements, lipid per oxidation of myocardium with oxidative stress, healing mechanisms of the damaged myocardium and a direct toxic effect of OPC on the myocardium (Kose et al., 2009).

The manifestations of cardiac injury may remain subclinical and masked with OP symptoms. It may be represented by cardiac arrhythmias and myocardial infarction (Vijayakumar et al., 2011).Cardiac injury may be serious and often fatal. Hence, early detection is crucial for applying preventive and supportive therapeutic strategies (Horacek et al., 2014).

Currently, the diagnosis of cardio toxicity is based mainly on changes in electrocardiography(ECG) and increased release of cardiac biochemical markers. However, definite myocardial injury is difficult to assess through ECG and in most patients, the initial ECG is non-diagnostic while the heart is suffering in a silent way (Cha et al., 2014).

All cardiac biomarkers are macromolecules found in cardiac myocytes and their appearance in the serum is indicative of myocyte injury and loss of sarcolemmal integrity (Green et al., 2008). They were considered important tools for diagnosis, risk assessment and therapeutic decision making in cardiovascular diseases (Felker et al., 2009).

Brain natriuretic peptide (BNP) and its $\mathrm{N}$-terminal fragment originate from a prohormone precursor molecule that is called "proBNP". It is released by the ventricular wall in response to myocyte stretch or stress due to inflammation and hypoxia. Once "proBNP" is released into the circulation, it is cleaved into "BNP" and "NTproBNP" with a half-life ranging from 20 minutes and 90-120 minutes respectively (DeFilippi et al., 2008). Minimal elevations of NT-pro BNP in asymptomatic patients are highly predictive of future cardiac events including mortality (Belagaviet al.,2012).

New prospective studies that compare $\mathrm{BNP} / \mathrm{NT}$ - pro BNP assays with wellestablished markers of cardio toxicity, such as creatine kinase-myocardial band (CK-MB)and Troponins are needed (O'Brien, 2008). The purpose of the present study was to investigate the potential benefit of NT-pro BNP as an early marker of cardio toxicity induced by acute OP poisoning and to compare the beneficial value of plasma NT-pro BNP with the wellassessed cardiac markers as CK-MB and Troponin I (cTnI). 


\section{SUBJECTS AND METHODS}

This randomized prospective comparative study got the approval of the local Research Ethical Committee. Informed consents were obtained from the studied individuals or persons on his/her behalf for participation in this study. Patients included in the study were treated according to the standard management guidelines of OP poisoning.

\section{Subjects:}

This study was conducted on 150 individuals of both sexes, 100 of them are acute OP poisoned cases, presented within 6 hours from exposure to the Toxicology Unit of Emergency Hospital of Mansoura University and the remaining 50 subjects are healthy individuals as a control group. This study was carried out during the period from the beginning of June 2012 to the end of June 2014. Participantswere divided into three groups:

Group I (control group): For laboratory evaluation of the baseline levels of pseudocholinesterase (PCE) and other studied cardiac biomarkers.

Group II: Included 38 OP poisoned patients without cardio toxic manifestations.

Group III: Included 62 OP poisoned patients with cardio toxic manifestations.
The diagnosis of acute OP poisoning based on toxic exposure to an OPC within 6 hours, as evidenced by history, physical examination and PCE level. The primary diagnosis of cardio toxicity based on the presence of hemodynamic instability and / or ECG abnormalities.

All patients were subjected to full history taking with special regard to demographic data, circumstances of exposure, OPC consumed, time elapsed between exposure and admission to hospital and any underlying diseases. Vital signs, gastrointestinal, respiratory and cardiovascular systems were assessed on admission.

\section{Exclusion criteria}

-All patients admitted to hospital more than six hours from exposure or had ingested other substances in addition to OPC.

- Patients with a history of cardiac disease, skeletal muscle trauma or disease, malignancy, patients on chemotherapy and patients older than 50 years.

- Patients with chronic malnutrition, liver damage and pregnant females.

- Patients on drugs that cause changes in heart rate or rhythm (bronchodilators, antidepressants, antipsychotics and anticholinergics).

\section{Sampling}

Eight milliliters venous blood sample was obtained under complete aseptic tech- 
nique; two milliliters were put in ethylene diamine tetra-acetic acid (EDTA) tube for determination of plasma NT-pro BNP and six milliliters in plain tube for determination of serum PCE, CK-MB and cTnI. Samples were centrifuged within $30 \mathrm{~min}$ of collection. The supernatant of plasma and sera were collected in labeled sterile containers and kept frozen at $-70^{\circ} \mathrm{C}$ until analysis except for PCE and CK-MB that were done sequentially.

\section{Methods}

- Measurement of PCE in the serum was done by spectrophotometer using Quimica Clinica Aplicada S.A. kits.

- Measurement of serum CK-MB was done by the Immune-Inhibition International Federation of Clinical Chemistry Method using ELI Tech clinical systems kits.

- Measurement of serum cTnI was done by the electrochemical-luminescence immunoassay "ECLIA" analyzers using Troponin I Short Turnaround Time kits.

- Measurement of plasma NT-pro BNP was done by spectrophotometer using "Sun Red human NT-pro BNP enzymelinked immune sorbent assay (ELISA) kits".

\section{Statistical Analysis}

All statistical procedures were performed using PRISM 5 (Graph Pad Software Inc., San Diego, CA). As data showed non-parametric distributions,
Mann-Whitney and Wilcoxon tests were used for comparison between twoOP poisoning groups (II and III), while Kruskal Wallis and multiple comparisons Dunn's post-tests were used for multiple groups comparisons. Fisher exact test and chisquare tests were used to study associations. For correlation, spearman rank correlation test was considered. Normally distributed variables were presented as mean \pm standard deviation (SD). P value was considered significant at values $\leq 0.05$.

\section{RESULTS}

In the present study, the number of studied population consisted of 150 subjects (67 males and 83 females) with age ranged from 6 to 50 years with a mean of age $35.3 \pm 11.5$ years. Fifty-nine percent of the studied OP poisoned cases were from rural areas and farmers represent $26 \%$ of OP poisoned cases.

As shown in table (1), sinus tachycardia appeared to be a more prominent cardiac sign $(32.2 \%)$ than sinus bradycardia (27.4\%) among group III. Hypotension and hypertension developed with the same percentage $(16 \%)$ in cases with cardiac signs. Thirty percent of cases presented with subnormal temperature. There were significant differences between cases with and without cardiac signs regarding pulse, blood pressure and axillary body temperature. 
According to Paradeniya Organophosphorus Poisoning (POP) scale of severity, there was significant difference between cases with and without cardiac signs regarding severity of poisoning as shown in table (2).

Out of 100 OP poisoned cases, $62 \%$ of cases showed abnormalities in ECG waves in the $1^{\text {st }}$ six hours of exposure. Increased corrected QT (QTc)interval (71\%), T wave inversion $(45 \%)$ and ST wave elevation
$(38.7 \%)$ were the most common ECG changes.

Regarding cardiac markers among studied cases, there was significant difference between control group and OP poisoned groups (II and III) regarding plasma NT-pro BNP levels on admission with no significant difference regarding serum CK-MB and Troponin I levels as shown in table (3).

Table (1) : Vital signs of the studied organophosphorus poisoned cases $(n=100)$ :

\begin{tabular}{|c|c|c|c|c|}
\hline Parameters & $\begin{array}{c}\text { GroupII } \\
\text { n (\%) }\end{array}$ & $\begin{array}{c}\text { GroupIII } \\
\text { n (\%) }\end{array}$ & $\begin{array}{c}\text { Total } \\
(\mathbf{n}=\mathbf{1 0 0})\end{array}$ & p-values \\
\hline $\begin{array}{l}\text { Pulse: } \\
\text { (1) Pulse rate }>100 / \mathrm{min} \\
\text { (2) Pulse rate } 60-100 / \mathrm{min} \\
\text { (3) Pulse rate }<60 / \mathrm{min}\end{array}$ & $\begin{array}{c}0 \\
38(100 \%) \\
0\end{array}$ & $\begin{array}{c}20(32.2 \%) \\
25(40.3 \%) \\
17(27.4 \%)\end{array}$ & $\begin{array}{l}20(20 \%) \\
63(63 \%) \\
17(17 \%)\end{array}$ & $<0.0001 * *$ \\
\hline $\begin{array}{l}\text { Bloodpressure: } \\
\text { (4) }<90 / 60 \mathrm{mmHg} \\
\text { (5) } 90 / 60-140 / 90 \mathrm{mmHg} \\
\text { (6) }>140 / 90 \mathrm{mmHg}\end{array}$ & $\begin{array}{c}0 \\
38(100 \%) \\
0\end{array}$ & $\begin{array}{l}10(16 \%) \\
42(68 \%) \\
10(16 \%)\end{array}$ & $\begin{array}{l}10(10 \%) \\
80(80 \%) \\
10(10 \%)\end{array}$ & $<0.0001^{* *}$ \\
\hline $\begin{array}{l}\text { Temperature: } \\
\text { (7) }<36.4{ }^{\circ} \mathrm{C} \\
\text { (8) } 36.4-37.2 \mathrm{C}^{\circ} \\
\text { (9) }>37.2{ }^{\circ} \mathrm{C}\end{array}$ & $\begin{array}{c}3(8 \%) \\
31(81.5 \%) \\
4(10.5 \%)\end{array}$ & $\begin{array}{c}27(43.5 \%) \\
35(56.5 \%) \\
0\end{array}$ & $\begin{array}{c}30(30 \%) \\
66(66 \%) \\
4(4 \%)\end{array}$ & $<0.0001^{* *}$ \\
\hline
\end{tabular}

* Significant at $\mathrm{p} \leq 0.05, \mathrm{n}=$ number, $\%=$ percentage.

Table (2) : Severity of the studied cases according to Paradeniya Organophosphorus Poisoning scale $(n=100)$ :

\begin{tabular}{|l|c|c|c|c|}
\hline \multicolumn{1}{|c|}{ POP scale } & $\begin{array}{c}\text { Group II } \\
\mathbf{n}(\mathbf{\%})\end{array}$ & $\begin{array}{c}\text { Group III } \\
\mathbf{n}(\mathbf{\%})\end{array}$ & $\begin{array}{c}\text { Total } \\
\mathbf{n}(\mathbf{\%})\end{array}$ & \multirow{2}{*}{ p-value } \\
\hline Mild & $14(36.9 \%)$ & $9(14.5 \%)$ & $23(23 \%)$ & \multirow{2}{*}{$0.0027^{*}$} \\
\hline Moderate & $17(44.7 \%)$ & $22(35.5 \%)$ & $39(39 \%)$ & \\
\hline Severe & $7(18.4 \%)$ & $31(50 \%)$ & $38(38 \%)$ & \\
\hline
\end{tabular}

* Significant at $\mathrm{p} \leq 0.05, \mathrm{n}=$ number, $\%=$ percentage, POP: Paradeniya Organophosphorus Poisoning. 


\section{Hasan et al}

Table (3) : Cardiac markers in control group versus organophosphorus poisoned groups (II and III) on admission:

\begin{tabular}{|l|c|c|c|}
\hline \multicolumn{1}{|c|}{ Cardiac markers } & $\begin{array}{c}\text { Control group } \\
\text { Mean } \pm \text { SD (min-max) }\end{array}$ & $\begin{array}{c}\text { OP poisoned groups } \\
\text { (II \&III) on admission } \\
\text { Mean } \pm \text { SD (min-max) }\end{array}$ & p-values \\
\hline CK-MB (IU/L) & $14.5 \pm 6.1$ & $\begin{array}{c}27 \pm 26.6 \\
(3-156)\end{array}$ & 0.1126 \\
\hline & $(2-25)$ & $0.19 \pm 0.35$ & 0.056 \\
Troponin I (ng/mL) & $0.08 \pm 0.002$ & $(0.04-2.1)$ & $<0.0001^{* *}$ \\
\hline
\end{tabular}

*Significant at $\mathrm{p} \leq$ 0.05, OP: organophosphorus, CK-MB: creatine kinase-myocardial band, NT-pro BNP: Nterminal pro Brain Natriuretic Peptides, SD: standard deviation, min: minimum, max: maximum.

On the other hand, there was significant difference between $\mathrm{OP}$ poisoned cases group II versus group III regarding plasma NT-pro BNP levels on admission with no significant differences regarding serum CK-MB and Troponin I levels as shown in table (4). Moreover, plasma NT-pro BNP was elevated above normal in $60.5 \%$ of cases without cardiac signs, from which $(15.8 \%)$ carried the high incidence for developing heart failure. On the other hand, it was elevated in all cases with cardiac signs $(100 \%)$, from which $(26 \%)$ carried the high incidence for developing heart failure.

Table (4) : Cardiac markers in organophosphorus poisoned cases without cardiac signs versus with cardiac signs on admission:

\begin{tabular}{|c|c|c|c|}
\hline $\begin{array}{l}\text { Cardiac markers } \\
\text { on admission }\end{array}$ & $\begin{array}{l}\text { OP poisoned } \\
\text { Groups }\end{array}$ & $\begin{array}{l}\text { Mean } \pm \text { SD } \\
(\min -\max )\end{array}$ & p-values \\
\hline \multirow{2}{*}{ CK-MB (IU/L) } & Without cardiac signs & $\begin{array}{c}21.7 \pm 22 \\
(5-98)\end{array}$ & \multirow{2}{*}{0.173} \\
\hline & With cardiac signs & $\begin{array}{l}30 \pm 28.7 \\
(3-156)\end{array}$ & \\
\hline \multirow{2}{*}{ Troponin I (ng/mL) } & Without cardiac signs & $\begin{array}{l}0.17 \pm 0.28 \\
(0.05-1.4)\end{array}$ & \multirow{2}{*}{0.7127} \\
\hline & With cardiac signs & $\begin{array}{c}0.2 \pm 0.38 \\
(0.04-2.1)\end{array}$ & \\
\hline \multirow{2}{*}{ NT-proBNP (pg/mL) } & Without cardiac signs & $\begin{array}{c}305.3 \pm 105.5 \\
(122-523)\end{array}$ & \multirow{2}{*}{$<0.0001^{* *}$} \\
\hline & With cardiac signs & $\begin{array}{c}387.6 \pm 66 \\
(301-578)\end{array}$ & \\
\hline
\end{tabular}

Significant at $\mathrm{p} \leq 0.05$, OP: organophosphorus, CK-MB: creatine kinase-myocardial band, NT-proBNP: Nterminal pro Brain Natriuretic Peptides, SD: standard deviation, min: minimum, max: maximum. 


\section{DISCUSSION}

The present work was carried out to assess the potential benefit of NT-pro BNP as an early marker of cardio toxicity induced by acute OP poisoning and to compare its beneficial value with the well assessed cardiac markers CK-MB and CTnI. There were statistically significant differences between cases of group II and III regarding their pulse, blood pressure and axillary temperature. Sinus tachycardia appeared to be a more prominent presentation than sinus bradycardia in OP poisoned cases with cardiac signs. Hypertension and hypotension developed with the same incidence and percentage in OP poisoned cases with cardiac signs, although none of them had previous history of blood pressure disorders. Agarwal et al. (2007) found that the nicotinic manifestations such as tachycardia and hypertension are the most common cardiac signs on presentation. Some investigators considered the presence of hypertension and sinus tachycardia as manifestations of severe OP poisoning (Karki et al., 2004).

On the other hand, hypotension may occur secondary to augmented vagal tone with muscarinic over stimulation and/or stimulation of vascular receptors by excessive circulating acetylcholine causing peripheral vasodilatation (Davies et al., 2008). As regard axillary temperature, 30\% of OP poisoned cases presented with sub- normal temperature $\left(<36.4 \mathrm{C}^{\circ}\right)$, most of them $(27 \%)$, showed cardiac signs. Similar results were previously reported by Moffatt et al. (2010).

Regarding POP scale of severity and peripheral cholinergic manifestations, there were statistically significant differences between OP poisoned cases in groups II and III. Similar results were previously reported by Siegal et al. (2009). Also Rehiman et al. (2008) stated that with increasing the severity of poisoning, the incidence of cardiac manifestations increased. On the other hand, $14.5 \%$ of OP poisoned cases exhibited cardiac signs although they were presented with mild manifestation. This can be explained by the fact that myocardial involvement from direct cardiac toxicity is patchy that may not manifest clinically while the heart is suffering in a silent way (Anand et al., 2009).

The most common ECG changes in this study were increased QTc interval, T wave inversion and ST wave elevation. Similar observations were reported by $\mathrm{Yu}$ rumez et al. (2009) and Vijayakumar et al. (2011). ECG abnormalities often accompany poisoning with OPC but their exact nature is not fully understood. Bizarre cardiac abnormalities can occur in the form of tachycardia, bradycardia and prolonged QTC and PR intervals, depending on whether nicotinic or muscarinic effect pre- 
dominates (Siegal et al., 2009). These ECG abnormalities may be serious and often fatal (Bar-Meir et al., 2007).

In the present study, the mean levels of CK-MB and cTnI were more elevated in cases of group III than group II on admission with no statistically significant differences between both groups. Similar results were previously reported by Yavuz et al. (2008), Wan et al. (2012) and Aghabiklooei et al. (2013).

Although elevation of serum CK-MB is a specific marker of acute myocardial infarction, Troponin I is more specific than CK-MB for myocardial injury because it is expressed only in cardiac muscle and has high sensitivity in detection of even small amounts of myocardial necrosis even before impairment of cardiac function. The magnitude of increase in serum Troponins correlates with the extent of myocardial injury (Thygesen et al., 2012).

Measurement of NT-pro BNP represents an interesting strategy for detecting subclinical cardio toxicity and reflects the hemodynamic status of the heart (Zidan et al., 2015). Jankowski (2008) and Felker et al. (2009) reported that if NT-pro BNP is elevated $>450 \mathrm{pg} / \mathrm{ml}$ in patients $<50$ years, heart failure is likely. In this study NT-Pro BNP was significantly higher in all OP poisoned cases with cardiac signs $(100 \%)$ from which $(26 \%)$ were $>450 \mathrm{pg} /$ $\mathrm{ml}$ and in $(60.5 \%)$ of OP poisoning without cardiac signs from which $(15.8 \%)$ were $>450 \mathrm{pg} / \mathrm{ml}$ within the $1^{\text {st }}$ six hours from exposure. Only plasma levels of NT-pro BNP showed highly significant differences among cases of OP poisoning with and without cardiac signs on admission.

This indicates that NT-pro BNP is an early specific marker for cardiac stress that may occur early within the $1^{\text {st }}$ six hours in $\mathrm{OP}$ poisoning than CK-MB or Troponin I. Moreover, its elevation in cases without cardiac signs reflected its value in detecting silent myocardial suffering during the acute OP poisoning. DeFilippi et al. (2008) stated that, whenever there is myocardial stress causing myocyte stretch, there will be active secretion of NT-pro BNP. Measurements of NT-pro BNP may be more effective for monitoring poisoninduced left ventricular dysfunction and early detection of myocardial stress(O'Brien, 2008).

This was accepted by CostelloBoerrigter et al. (2006) and Porapakkham et al. (2010) who stated that NT-pro BNP is a sensitive marker for cardiac dysfunction. An elevated NT-pro BNP level always indicates the presence of an underlying cardiac disorder and levels correlate directly with the severity of disorder. On the other hand, a normal NT-pro BNP level virtually excludes cardiac dysfunction. 


\section{CONCLUSION}

From the current work, it can be concluded that NT-pro BNP can be used as a significant diagnostic screening tool for silent myocardial suffering and stress that may occur early during the course of acute OP poisoning than $\mathrm{CTnI}$ and CK-MB, allowing for early specific cardio-protective therapies.

\section{REFERENCES}

Aardema, H.; Meertens, J.; Ligtenberg, J.; et al. (2008): "Organophosphorus pesticide poisoning: Cases and developments". Neth. J. Med., 66 (4):149-153.

Agarwal, S. B.; Bhatnagar, V. K.; Agarwal, A.; et al. (2007): "Impairment in clinical indices in acute organophosphorus poisoning patients in India". The Internal Journal of Toxicology, 4 : 4-5.

Aghabiklooei, A.; Mostafazadeh, B.; Farzaneh, E. and Morteza, A. (2013): "Does organophosphate poisoning cause cardiac injury?" Pak. J. Pharm. Sci.; 26 (6):1247-1250.

Anand, S.; Singh, S.; Saikia, U. N.; et al. (2009): "Cardiac abnormalities in acute organophosphate poisoning". Informa. Health Care-Clinical Toxicology, 47 (3): 230-235.
Bar-Meir, E.; Schein, O.; Eisenkraft, A.; et al. (2007): "Guidelines for treating cardiac manifestations of organophosphates poisoning with special emphasis on long QT and Torsades De Pointes". Critical Reviews in Toxicology, 37(3): 279-285.

Belagavi, A.C.; Rao, M.; Pillai, A.Y. and Srihari, U.S. (2012): "Correlation between NT pro BNP and left ventricular ejection fraction in elderly patients presenting to emergency department with dyspnea". Indian Heart J., 64 (3): 302-304.

Cha, Y.S.; Kim, H. and Go, J. (2014): "Features of myocardial injury in severe organophosphate poisoning". Clinical Toxicology, 52 (8): 873-879.

Costello-Boerrigter, L.C.; Boerrigter, G. and Redfield, M.M. (2006): "Aminoterminal pro-B-type natriuretic peptide and B-type natriuretic peptide in the general community: Determinants and detection of left ventricular dysfunction". J. Am. Coll. Cardiol., 47 (2): 345-353.

Davies, J.O.; Roberts, D.; Eyer, P.; et al. (2008): "Hypotension in severe Dimethoate self-poisoning". Clin. Toxicol. (Phila), 46 (9): 880-884.

DeFilippi, C.; van Kimmenade, R. and Pinto, Y. M. (2008): "Amino-terminal pro-B-type natriuretic peptide testing in renal disease". Am. J. Cardiol., 101:82-88. 
Felker, G.M.; Hasselblad, V.; Hernandez, A.F. and O'Connor, C.M. (2009): “Biomarker-guided therapy in chronic heart failure: A meta-analysis of randomized controlled trials". Am. Heart J., 158(3):422430.

Green, S. M., Martinez-Rumayor, A. and Gregory, S. A. (2008): "Clinical uncertainty, diagnostic accuracy and outcomes in emergency department patients presenting with dyspnea". Arch. Intern. Med.; 168:741-748.

Horacek, J. M.; Vasatova, M.; Pudil, R.; et al.(2014): "Biomarkers for the early detection of anthraccline-induced cardio toxicity: current status". Biomedical Papers, 158: (4):511-517.

Jankowski, M. (2008): "B-type natriuretic peptide for diagnosis and therapy". Recent Pat. Cardiovasc. Drug Discov., 3 (2): 77-83.

Karki, P.; Ansari, J. A.; Bhandary, S. and Koirala, S. (2004): "Cardiac and electrocardiographical manifestations of acute organophosphate poisoning". Singapore Med. J., 45(8): 385-389.

Kose, A.; Gunay, N.; Yildirim, C.; et al. (2009): "Cardiac damage in acute organophosphate poisoning in rats: Effects of atropine and pralidoxime". Am. J. Emerg. Med., 27:169-175.
Kumar, S. V.; Fareedullah, Y.; Sudhakar, B.; et al. (2010): "Current review on organophosphorus poisoning". Archives of Applied Science Research, 2 (4): 199215.

Moffatt, A.; Mohammed, F. and Eddeston, M. (2010): "Hypothermia and fever after organophosphorus poisoning in humans: A prospective case series". J. Med. Toxicol., 6 (4): 379-385.

O'Brien, P. J. (2008): “Cardiac Troponin is the most effective translational safety biomarker for myocardial injury in cardio toxicity". Toxicology, 245 (3): 206-218.

Porapakkham, P.; Zimmet, H.; Billah, B. and Krum, H. (2010): "B-type natriuretic peptide-guided heart failure therapy: A meta-analysis". Arch. Intern. Med., 170 (6): 507-514.

Rehiman, S.; Lohani, S. P. and Bhattarai, M. P. (2008): “Correlation of serum cholinesterase level, clinical score at presentation and severity of OP poisoning." J. Nepal Med. Assoc., 47 (170): 47-52.

Siegal, D.; Kotowycz, M.A. and Methot, M. (2009): "Complete heart block following intentional carbamate ingestion". Can. J. Cardiol., 25(8): 473-480.

Thygesen, K.; Alpert, J. S. and Jaffe, 
A.S. (2012): "Third universal definition of myocardial infarction". Circulation, 126: 2020.

Vijayakumar, S.; Fareedullah, M.; Ashok, K.E. and Mohan, R.K. (2011): "A prospective study on electrocardiographic findings of patients with organophosphorus poisoning". Cardiovasc. Toxicol., 11: 113-117.

Wan, W. G.; Jiang, L.; Zheng, S. C.; et al. (2012): "Comprehensive analysis on variation of cardiac enzyme and troponin induced by acute organophosphorus poisoning". Zhonghua Lao Dong Wei Sheng Zhi Ye Bing ZaZhi, 30 (6): 452-455.
Yavuz, Y.; Yurumez, Y.; Ciftci, I.H.; et al. (2008): "Effect of diphenhydramine on myocardial injury caused by organophosphate poisoning". Clin. Toxicol. (Phila); 46: 67-70.

Yurumez, Y.; Yavuz, Y.; Saglam, H.; et al. (2009): "Electrocardiographic findings of acute organophosphate poisoning". J. Emerg. Med., 36(1) :39-42.

Zidan, A.; Sherief, L. M.; El-Sheikh, A.; et al. (2015): "NT-pro BNP as early marker of subclinical late cardio toxicity after doxorubicin therapy and mediastinal irradiation in childhood cancer survivors". Disease Markers: 1-10. 


\section{إن تر مينال بروناتريوريتيك ببتيد في البلازها كدلالة مبكرة على تسهمم القلب الناجم عن مركبات الفوسيت سفات العضوية}

$$
\text { المثتركون فى البحث }
$$

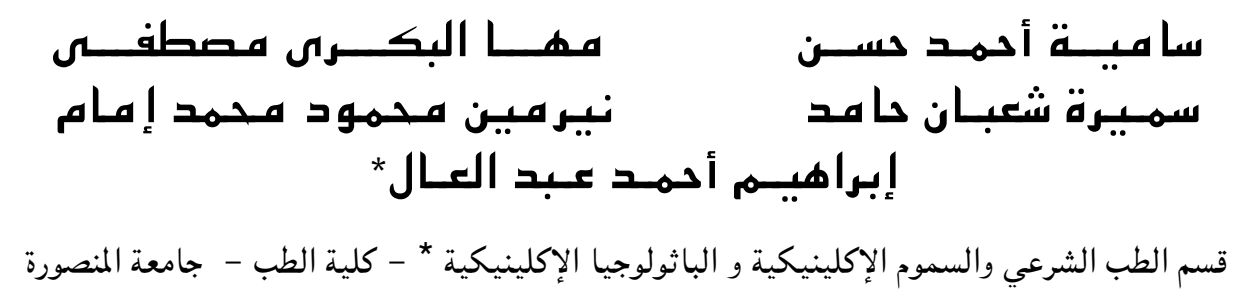

مازال التسمم بمركبات الفوسفات العضوية يعد سببًا هاما من أسباب الاعتلال والوفيات في البلدان النامية ومضاعفات القلب غالبا ما ترافت التسمم بتلك المركبات والتي يمكن تفاديها بالاكتشاف المبكر وعلاجها على نحو كاف.لذلك هدفت هذه الدراسة إلى تقييم الفوائد المحتملة

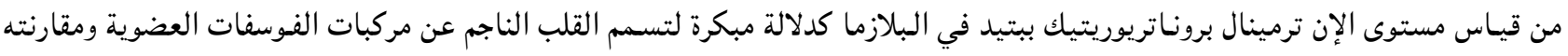

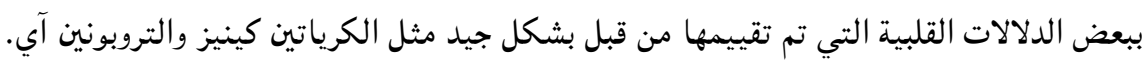



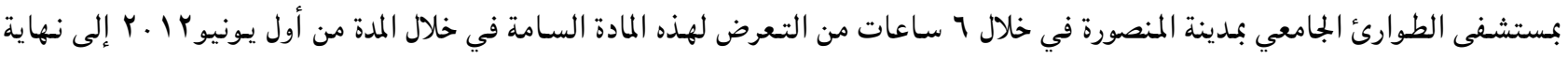
يونيو ع ا.Y. أما الخمسون الباقون فهم أفراد متطوعون.

وقد تم تقسيم أفراد البحث إلى ثلاث مجموعات : المجموعة الأولي (مجموعة ضابطة) وهي عبارة عن خمسين فردًا من المتطوعين الذين لا

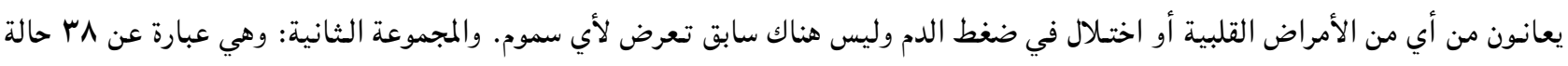

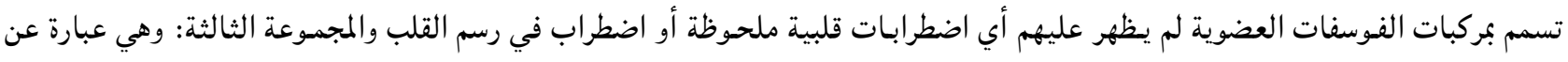

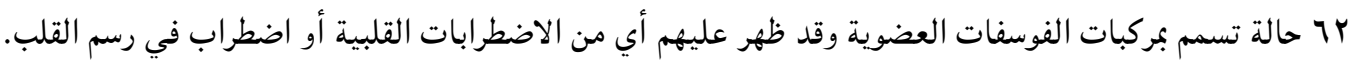
وقد تم قياس مستوي السودوكولين إستيريز والكرياتين كينيز وتروبونين آي في السيرم والإن ترمينال بروناتريوريتيك ببتيد في البلازما في خلال الستة ساعات الأولي من التسمم. وقد أظهرت النتائج أن الإن ترمينال بروناتريوريتـيك هو الوحيد من الدلالات القلبية البيوكيميائية الذي أظهر فرقا ذو دلالة إحصائية كبيرة

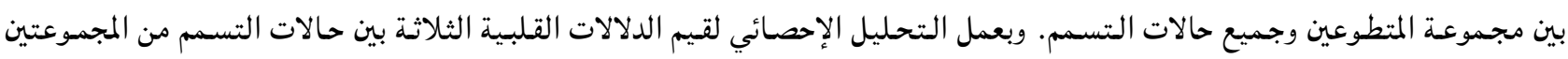

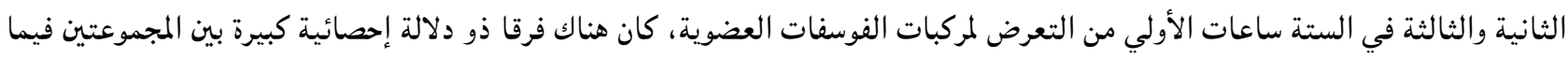

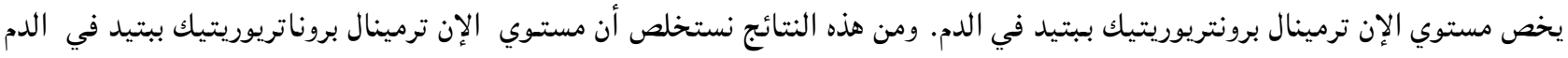

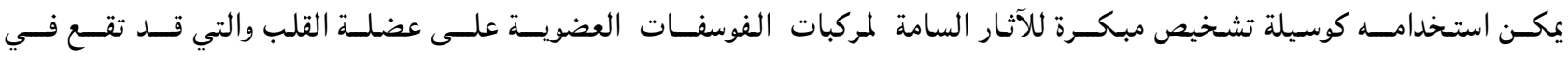

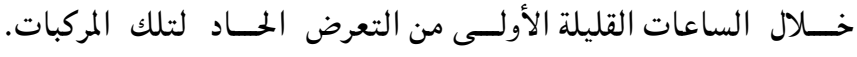

